\title{
MONETARY POLICY AND CYCLICAL SYSTEMIC RISK - FRIENDS OR FOES?
}

\section{Łukasz Kurowski, Paweł Smaga*}

\begin{abstract}
We explore the procyclicality of monetary policy decisions towards the financial cycle in the 1995-2015 period on a sample of seven central banks. Using the real interest rate gap and the credit-to-GDP gap, we provide evidence that monetary policy procyclicality is a material issue occurring in more than $50 \%$ of observations in expansionary phase of financial cycle. It indicates that the central bank faces conflicting objectives of price and financial stability (as proxied by cyclical systemic risk). Nevertheless, taking into consideration all financial cycle phases, complementariness between price and financial stability is more frequent than cases with conflicting objectives in the UK, Euro Area and the US. The occurrence of potential procyclical behaviour of monetary policy (especially in the financial cycle expansion phases) underlines the need for proactive macroprudential policy.
\end{abstract}

Keywords: financial stability, macroprudential policy, monetary policy, financial cycle JEL Classification: E52, E58, E61, G18

\section{Introduction}

Since the onset of the Global Financial Crisis (GFC), maintaining financial stability has been the key concern of policymakers. The scale of negative effects caused and the resulting losses in the real economy underline the need to pre-emptively safeguard financial stability. The Jackson Hole paradigm is no longer valid, and both price stability and financial stability are currently the two indispensable pillars of economic stability. However, this situation raises the question of the evolving role of monetary policy (the leaning vs. cleaning debate) as well as the interactions between price and financial stability. There is no question of whether or not both policies interact, rather what is the potential trade-off between achieving both goals at the same time.

For example, although an excessively loose monetary policy (i.e. the low-level interest rates) is conducive to price stability, it may fuel the procyclical cumulative build-

* Lukasz Kurowski, Warsaw School of Economics (Institute of Finance) and National Bank of Poland, Poland (lukaszkurowskisgh@gmail.com);

Pawel Smaga, Warsaw School of Economics (Institute of Finance) and National Bank of Poland, Poland (psmaga@sgh.waw.pl) - corresponding author.

The paper was written as a part of statutory research grant at the Warsaw School of Economics in 2016 (No. KZIF/S/17/16) entitled "Size and Structure of Financial Sectors in Selected Central and Eastern European Countries and Developed Countries. Convergence or Own Path?" prepared under the guidance of M. Iwanicz-Drozdowska, to whom and to two anonymous reviewers we are very grateful for helpful comments to the early draft of the paper. We explicitly stress that the opinions expressed herein are those of the authors and do not reflect those of the associated institutions. 
up of financial imbalances at the same time (Borio et al., 2016). This study aims to assess the extent to which monetary policy stance (as proxied by the real interest rate gap) was countercyclical or procyclical towards the financial cycle (as proxied using credit/GDP gap) on the sample of seven central banks from both post-communist economies (Poland, Hungary and the Czech Republic) and four from advanced countries (the UK, Sweden, the US and Euro Area) over the period of 1995-2015.

The contributions of this research are twofold. First, we assess the co-movement between the monetary policy stance and the phases of the financial cycle in seven countries. This is in contrast to previous studies focussing on the effect of monetary policy on the business cycle only, and we prove that the procyclicality of monetary policy towards financial cycle is material. Second, we empirically investigate the extent of potential conflicts between achieving inflation target and stabilizing the financial cycle on the basis of the theoretical framework provided by Beau et al. (2012) and find that these conflicts are not negligible, especially in the expansive phase of financial cycle. To the best of our knowledge, this investigation has been done only to a limited extent in the literature.

This paper is organised as follows. In the second section, we review the relevant literature on financial cycles and monetary policy effect on cyclical systemic risk. In the third part, we discuss the methodology applied and outline the data sources used. The fourth part contains stylised facts about monetary policies and financial cycles in the analysed countries. The fifth section presents the empirical results of monetary policy procyclicality and the final section concludes.

\section{Literature Review on Monetary Policy and Financial Cycle}

Procyclicality, as a cyclical dimension of systemic risk, might be regarded as self-reinforcing cyclical fluctuations in risk and leverage and their distribution within the financial system (Smaga, 2014). It strengthens interconnectedness within the financial sector and may negatively affect economic growth (Olszak and Pipień, 2016). Procyclicality is especially pronounced in the banking sector, and it is mainly due to both exogenous and endogenous factors (Athanasoglou et al., 2014).

Financial cycles are considerably distinct from business cycles. Financial cycles are longer, deeper, with much greater amplitude than business cycles, but with lower frequency (Hiebert et al., 2014). Financial cycles are a medium to long-term phenomenon as opposed to a short-term business cycle. The length and amplitude of financial cycles also depend on the given financial regime, monetary regime and real-economy regime. Both the duration and amplitude of the financial cycle have increased since the mid-1980s, with an average duration of around 16 years (Borio, 2014a).

Although distinct, business and financial cycles are closely interlinked. Kollintzas et al. (2011) prove that a positive correlation exists between procyclical monetary aggregates and GDP. Further, Claessens et al. (2011) show using a sample of 44 countries in the period of 1960-2010 that recessions associated with financial disruptions, notably house and equity price busts, tend to be longer and deeper than other recessions because financial 
cycle peaks are closely associated with financial crises (Borio, 2014a; Stremmel, 2015). At the same time, recoveries following asset price busts tend to be weaker, but recoveries associated with rapid growth in credit and house prices are usually stronger.

However, both business and financial cycles are more pronounced in emerging markets (EMEs) than in advanced countries. In a panel of 71 countries from 1970 to 2012, Calderon and Fuentes (2014) arrive at the conclusion that recessions in the EMEs are deeper, steeper and costlier than those in industrial countries, and that this condition is associated with a higher incidence of crises in the EMEs. Recoveries in the EMEs are stronger but slower and more volatile than those in industrial countries. During crisis-related downturns, real credit and asset prices tend to be more volatile in the EMEs than regular recessions. Moreover, peaks in a financial cycle tend to precede peaks in a business cycle during crises in the EMEs. Financial cycles are increasingly being determined by the global financial cycle (Bauer et al., 2016), thereby reducing the effect of conventional monetary policy on the "national" financial cycle.

Table 1 | Monetary Policy Instruments and Financial Stability - Review of Impact Channels

\begin{tabular}{|c|c|c|c|}
\hline $\begin{array}{l}\text { Impact } \\
\text { Channel }\end{array}$ & Source & $\begin{array}{l}\text { Monetary Policy } \\
\text { Instrument }\end{array}$ & $\begin{array}{l}\text { Effect on Financial Stability/ } \\
\text { Financial Cycle }\end{array}$ \\
\hline \multirow{3}{*}{$\begin{array}{l}\text { Balance } \\
\text { sheet }\end{array}$} & Illing, 2007 & $\begin{array}{l}\text { Liquidity injection } \\
\text { programmes }\end{array}$ & $\begin{array}{l}\text { Increase in leverage and excessive } \\
\text { asset price movements }\end{array}$ \\
\hline & Shin, 2008 & $\begin{array}{l}\text { Liquidity injection } \\
\text { programmes in case } \\
\text { of poorly capitalised } \\
\text { institutions }\end{array}$ & $\begin{array}{l}\text { Credit expansion and increase in total } \\
\text { assets of financial institutions, thus } \\
\text { leading to asset price growth and } \\
\text { additional balance sheet expansion }\end{array}$ \\
\hline & Persson, 2009 & Interest rate cut & $\begin{array}{l}\text { Increase in over-indebtedness } \\
\text { of households and nonfinancial } \\
\text { corporations }\end{array}$ \\
\hline \multirow{3}{*}{$\begin{array}{l}\text { Risky } \\
\text { behaviour }\end{array}$} & $\begin{array}{l}\text { loannidou et al., } 2008 \text {, } \\
\text { Jiménez et al., } 2008\end{array}$ & Interest rate cut & $\begin{array}{l}\text { Higher share of loans provided to } \\
\text { borrowers with worse creditworthiness }\end{array}$ \\
\hline & Nicolo et al., 2010 & Interest rate cut & Search for yield behaviour \\
\hline & Landier et al., 2011 & Interest rate increase & $\begin{array}{l}\text { Higher exposure to the risk of real } \\
\text { estate price changes }\end{array}$ \\
\hline \multirow{3}{*}{$\begin{array}{l}\text { Asset } \\
\text { prices and } \\
\text { exchange } \\
\text { rate }\end{array}$} & Taylor, 2007 & Interest rate cut & $\begin{array}{l}\text { Higher level of asset prices (in 2001- } \\
2005 \text { in the US) }\end{array}$ \\
\hline & $\begin{array}{l}\text { Merrouche and Nier, } \\
2010\end{array}$ & Interest rate cut & $\begin{array}{l}\text { Strengthening financial imbalances } \\
\text { in other countries-higher exchange } \\
\text { rate volatility }\end{array}$ \\
\hline & IMF, 2013 & Interest rate increase & $\begin{array}{l}\text { Increase in the share of foreign } \\
\text { currency loans }\end{array}$ \\
\hline
\end{tabular}

Source: Authors 
Irrespective of their primary goal, monetary policy instruments affect financial stability and the financial cycle (see Table 1). The strength and direction of monetary policy decisions affecting systemic risk depend on the source of systemic risk (IMF, 2013). If the balance sheet structure of monetary financial institutions is the source of systemic risk, then the central bank's policy involving liquidity programmes increases their leverage (e.g. through risk assessment models; see e.g. Illing, 2007).

Reduction in interest rates, as a main monetary policy instrument, can be a "doubleedged sword." In the short term, it decreases credit risk but encourages clients to take more debt and increase their level of the over-indebtedness in the medium term (Jiménez et al., 2008). Several studies have shown that the reduction of interest rates may induce banks to provide loans to riskier borrowers with worse creditworthiness. The high level of risktaking behaviour is observed in small banks and cooperative banks (e.g. Ioannidou et al., 2008, Jiménez et al., 2008). Further, interest rates that turn negative exacerbate the search for yield behaviour. Ultra-low or negative interest rates encourage investors to search more profitable and risky investment opportunities (Nicolo et al., 2010).

Monetary policy affects systemic risk through asset prices, currency and capital flows channels. Taylor (2007) shows a significant correlation between monetary policy decisions and asset prices in the period of 2001-2005. Expansionary monetary policies induce capital flows, which may increase financial imbalances (Merrouche and Nier, 2010). In a negative interest rate environment, capital flows between countries may force central banks to cut interest rates to stop the currency exchange appreciation. However, if the source of systemic risk is foreign currency loans, restrictive monetary policies will amplify the accumulated risk and exposure to foreign exchange volatility (IMF, 2013). Moreover, Agur and Demertzis (2012) identify the substitution effect related to restrictive monetary policies. When the interest rate increases, balance sheet items levered by the banking sector become more expensive. Therefore, banks strive to lever less, thus lowering risk taking.

Thus, the following question remains: Should monetary policy, which aims to stabilise price, consider the financial cycle? Delis and Karavias (2015) show that the "optimal" monetary policy targeting stabilisation of the business cycle simultaneously forces the level of banks' credit risk out of equilibrium. The optimal policy dampens the strength of financial amplification by responding to the drivers of uncertainty shocks in stress periods, even if doing so is at the expense of creating a mild degree of fluctuations in inflation (Fendoglu, 2014). However, Baxa et al. (2013) find that the degree of financial stress effect on the changes in interest rate setting is nil when the levels of stress are moderate.

A financial cycle is usually measured best with the credit-to-GDP gap. The most promising leading indicators of financial crises are gaps of the ratio of (private sector) credit-to-GDP and asset prices, especially property prices (Borio and Drehmann, 2009), as combining them appears to capture the link among the financial cycle, business cycle and crises. Borio et al. (2012) and Giese et al. (2014) show that financial cycle is effectively identified by the co-movement of cycles in credit and property prices aside from the creditto-GDP gap. The ESRB (2014) finds that the credit-to-GDP gap is the best single leading indicator for systemic banking crises associated with excessive credit growth for both 
the EU as a whole and for the majority of EU countries, including for CESEE countries (Geršl and Seidler, 2015).

The literature on financial cycles and on the interactions between various phases of real and financial cycles is relatively new and blossomed after the GFC. Many empirical studies have been conducted on the monetary policy effect on the business cycle (see e.g. Kaminsky et al. (2005), McGettigan et al. (2013). However, to our knowledge, the potential effect of monetary policy on a financial cycle has been explored only to a limited extent to date. Therefore, we attempt to address this gap.

\section{Methodology and Data}

To assess the cyclical behaviour of monetary policies, we analyse three post-communist countries (Hungary, the Czech Republic and Poland) and four advanced countries/regions (the United Kingdom, Sweden, the US and euro area). We use OECD data ${ }^{1}$ and data from central bank websites for the quarterly inflation rates. As a proxy for monetary policy decisions we analyse the official interest rates assuming the level of quarterly interest is given as an average of daily rates. We assess the quarterly monetary policy stance in each country/region over the period of 1995-2015 based on the real interest rate gap calculated using Kalman filter (Holston et al., 2016) ${ }^{2}$. Therefore the real interest rate gap is a difference between actual real interest rate and the natural real rate, which better determines intertemporal substitution of agents and can be used as a proxy for the monetary policy stance. Comparing to the dynamic general equilibrium models, Kalman filter focuses on higher frequency components, what should be considered as an advantage in a natural rate calculation (Giammarioli and Valla, 2004).

We use quarterly country-level data on the credit-to-GDP ratio ${ }^{3}$ from the fourth quarter of 1995 to the fourth quarter of 2015 obtained from the Bank for International Settlement database $^{4}$ (data series for euro area starts from the first quarter of 1999) for Hungary, the Czech Republic, Poland, euro area, Sweden and the US.

As previously mentioned, the long-term credit-to-GDP ratio performs well in assessing the build-up of the financial cycle (financial imbalances). Different methods are used to calculate financial cycle trends (e.g. Christiano-Fitzgerald filter, Kalman filter and Baxter-King filter; see Mohr (2005)). For the purpose of our research, the long-term trend of credit-to-GDP ratio is calculated using Christiano-Fitzgerald filter with a band of 32 to 120 quarters (Drehmann et al., 2012). This band range used in the filter is motivated by the observation that financial cycles are about four times longer than business cycles and that systemic crises tend to occur once every 20-25 years (BSCB, 2010). We choose the $\mathrm{CF}$ filter because it allows to unambiguously define the phases of the financial cycle in the whole sample.

\footnotetext{
1 https://data.oecd.org/price/inflation-cpi.htm (accessed 20 May 2017)

2 For key inputs we use HP filter with $\lambda=1600$.

3 The ratio includes credits to the private non-financial sector.

4 http://www.bis.org/statistics/totcredit.htm (accessed 20 May 2017)
} 
Subsequently, we analyse the monetary policy stance. For the purpose of the study, expansive monetary policy is defined as the period (number of quarters) when real interest rate gap is negative. Restrictive monetary policy is defined as the opposite.

To check behaviour of monetary policy towards financial cycle, we calculate the share of quarters in the whole sample when each monetary policy stance (expansive and restrictive) is associated with each financial cycle phases (expansion, slowdown, depression and recovery).

$$
M P A_{s, f}=\frac{m_{s, f}}{n}
$$

MPA (monetary policy approach towards financial phase) equals the share of observation with monetary policy stance $s$ in financial cycle phase $f$ and $n$ is a total number of observations (quarters in the sample). We assess the behaviour of monetary policies towards cyclical systemic risk according to a dynamic approach (changes in the credit-to-GDP gap level). We follow the research approach of Malovaná and Frait (2016) who used the credit-toGDP to analyse causality between monetary and macroprudential polices in a time-varying coefficient panel VAR model. A similar approach was also taken by Claessens et al. (2011), who developed the measure of cycle synchronisation based on the gap change.

Table 2 | Monetary Policy and Financial Cycle Gap: A Dynamic Approach

\begin{tabular}{|c|c|c|c|c|}
\hline \multirow{2}{*}{$\begin{array}{l}\text { Monetary } \\
\text { Policy/Gap }\end{array}$} & \multicolumn{2}{|c|}{$\begin{array}{l}\text { Positive Financial Cycle Gap Level } \\
\text { in Quarte } i\end{array}$} & \multicolumn{2}{|c|}{$\begin{array}{l}\text { Negative Financial Cycle Gap Level } \\
\text { in Quarter i }\end{array}$} \\
\hline & $\begin{array}{c}\Delta \text { gap }>0 \\
\text { (expansive phase) }\end{array}$ & $\begin{array}{c}\Delta \text { gap }<0 \\
\text { (slowdown phase) }\end{array}$ & $\begin{array}{c}\Delta \text { gap }<0 \\
\text { (depression phase) }\end{array}$ & $\begin{array}{c}\Delta \text { gap }>0 \\
\text { (recovery phase) }\end{array}$ \\
\hline $\begin{array}{l}\text { Expansive } \\
\text { in quarter } i\end{array}$ & $\begin{array}{l}\text { Procyclical } \\
\text { (build-up of cyclical } \\
\text { imbalances) }\end{array}$ & Neutral & $\begin{array}{l}\text { Counterclical } \\
\text { (reduction of cyclical } \\
\text { imbalances) }\end{array}$ & Neutral \\
\hline $\begin{array}{l}\text { Restrictive } \\
\text { in quarter } i\end{array}$ & $\begin{array}{l}\text { Counterclical } \\
\text { (reduction of cyclical } \\
\text { imbalances) }\end{array}$ & Neutral & $\begin{array}{l}\text { Procyclical } \\
\text { (build-up of cyclical } \\
\text { imbalances) }\end{array}$ & Neutral \\
\hline
\end{tabular}

Source: Authors

We also assume that we cannot assess the behaviour of monetary policy towards financial imbalances when credit-to-GDP gaps (positive and negative) are closing (in slowdown and recovery phases, see Table 2). When a positive financial cycle gap increases on a quarterly basis ( $\Delta$ positive gap $>0$ ), the expansive monetary policy is building up financial imbalances (is procyclical towards financial cycle). This approach is similar to the situation in which the interest rate decreases and the asset price bubble builds up (Bordo and Lane, 2012). Similar procyclicality appears when restrictive monetary policy is associated with depression in financial cycle (negative and expanding financial cycle gap). In this situation, an increase in the interest rate leads to further fall in credit flow, which is already below the trend. Beau at al. (2012) described this situation as one in which financial deflation occurs when inflation reaches values above the target. 
We consider restrictive monetary policies to reduce cyclical financial imbalances (be countercyclical) when a financial cycle gap is positive and increases on a quarterly basis. A similar case involves an expansive monetary policy and depression phase. When a financial cycle gaps closes (slowdown and recovery), the monetary policy behaviour towards cyclical imbalances is defined as neutral. The cases of the monetary policy behaviour towards cyclical systemic risk are defined based on Table 2 .

The key indicator for monetary policy is the price level. Therefore, we compare deviation of inflation rate from inflation target with financial cycle phases. We calculate it in two cases - using the actual value of inflation rate and expected values of inflation. Expected values of inflation (4 quarters ahead) were obtained using OLS regression with trend extrapolation methodology:

$$
\pi_{t}^{e}=\mu_{0}+\pi_{t-1}+\mu_{1}\left(\pi_{t-1}-\pi_{t-2}\right),
$$

where $\pi$ indicates inflation level and $\mu_{0}, \mu_{1}$ are equation parameters. Such trend extrapolation approach was used for example by Ross and Schmidt (2011), Blanchard et al. (2015) and reflects accommodative inflation expectations. In case of medium-term monetary policy strategy (for example in Poland since 1998 to 2004) the inflation target in the each quarter was set up based on the logarithmic interpolation. We show estimation results for expected inflation in Appendix.

\section{Stylised Facts about Monetary Policies and Financial Cycles}

The monetary policy frameworks are similar in the analysed central banks, as they all announced numerical inflation target. Adapting inflation targeting strategy is a result of the gradual strengthening of monetary policy frameworks in NBP, MNB and CNB after the transformation and of the legal amendments induced by the requirements of membership in the ESCB. Central banks' fledgling monetary policy frameworks in Poland, the Czech Republic and Hungary faced legacy problems of the former regime and the ensuing transformation crises in the 1990s of the 20th century (i.e. hyperinflation, easing the transition into a free-floating currency regime and maintaining nascent banking sector stability). Over the course of time, their monetary policy frameworks began to catch up, while dealing with the risks of converging small open economies (e.g. excessive credit growth), as fostered by the increasing role of foreign capital in the banking sector (Iwanicz-Drozdowska and Witkowski, 2016). On the contrary, central banks in the United Kingdom, euro area, Sweden and the US were more experienced in the conduct of monetary policy, faced less volatile inflation and more stable currencies, and operated in significantly larger economies and banking sectors. In terms of financial stability objectives, the mandates of the analysed central banks were defined or strengthened only after the recent GFC, along with entrusting central banks with the (leading) role in macroprudential policy. Thus, the monetary policies in the period pre-GFC had lower incentive to consider the financial cycle. 
Figure 1 | Financial Cycles and Real Interest Rate Gap Paths in 1995-2015

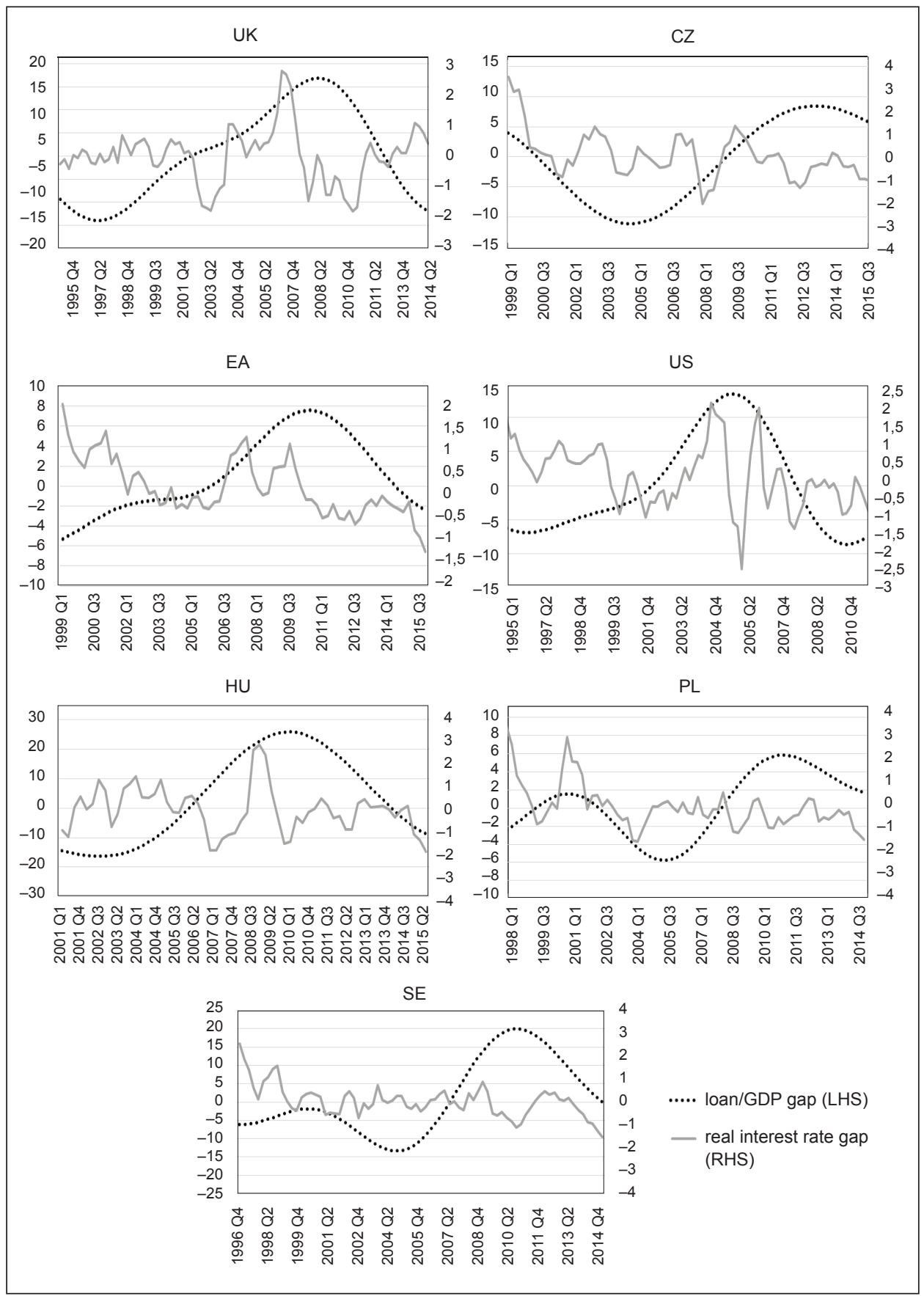

Source: own calculations based on BIS data. 
The development of financial cycles in our sample differed in the period of 1995-2015 (see Figure 1). The peaks in credit-to-GDP gap were recorded early in the US, UK, the euro area and Hungary, while in Poland, Sweden and the Czech Republic the peaks were observed much later. In each country, amplitude of the gap level varies, thus indicating a diverse scale of cyclical systemic risk accumulation. Gap volatility was the highest in the United Kingdom and Hungary and the lowest in the Euro Area and Poland. On average, the highest credit-toGDP gaps were recorded in Hungary and Sweden (close to 20 p.p.). In the Euro Area, Poland and the Czech Republic, the gaps did not exceed 10 p.p. over the analysed period.

The real interest rate gap paths in the sample period were similar in the Czech Republic, the euro area, Poland and Sweden. In the late 1990s interest rates were on record high levels but since then have started to decline gradually. Recently, real interest rates have gone into the negative territory or have remained at a very low level, reflecting prolonged expansive monetary policy.

\section{Cross-Country Results}

We conduct the analysis in two stages. First, we compare the monetary policy stance (expansive/restrictive) with four financial cycle phases (by aggregating the outcomes of MPA for each country in each quarter) to assess procyclical or countercyclical outcomes. Yet, we acknowledge that impact of interest rate change on the financial cycle might be additionally influenced by realized shocks that also drive the financial cycle at the same time. Such shocks include e.g. sudden repricing of risk premia, credit supply and demand shocks or shocks related to real estate. Therefore, we interpret the monetary policy stance as a factor potentially contributing to, but not solely determining the cyclical systemic risk. Second, from the policy perspective, we analyse the potential degree of conflicts between price and financial stability objectives by comparing the level of (both current and expected) inflation rate (above or below the numerical inflation target) in four financial cycle phases.

We defined monetary policy as procyclical when monetary expansion accelerates the existing expansionary phase of the cycle or when restrictive monetary policy amplifies the depression in the financial cycle. On the contrary, monetary policy works countercyclically when it is restrictive in expansionary phase of the cycle or expansionary in the cyclical depression. Results for such cases are presented in Table 3.

Several conclusions might be drawn from Table 3 . The procyclicality of monetary policy exists in $40-70 \%$ of cases in an expansionary financial cycle phase (e.g. in euro area, US and Poland). It is in general less visible in times of cyclical depression ( $0-55 \%$ of cases). The countercyclical monetary policy is also more frequent in the depression phase of financial cycle (45-100\% of cases, e.g. in the Euro Area and in the US) than in the expansionary phase $(30-58 \%, e . g$. in the Euro Area and in the UK). The procyclicality of monetary policy is on average the lowest (and consequently its countercyclical stance the highest) in the Euro Area and in the US and UK - countries with significant banking sectors. In this group of countries, there are more instances of countercyclical than procyclical monetary policy. At the same time procyclicality of monetary policy is on average a bit higher in countries with relatively smaller banking sectors in the Czech Republic, Poland and Hungary (except 
for Sweden), where there are more frequent cases with monetary policy being procyclical, rather than countercyclical. This might be due to their lower effectiveness of their monetary policies. The effectiveness of monetary transmission channels in small open economies is often reduced by dominant impact of global interest rates. Thus, the ability to shape business and financial cycles by those countries is limited (Bauer et al., 2016). Therefore it is harder to assess the approach of national monetary policy towards the (national) financial cycle.

Table 3 | Monetary Policy Stance in Financial Cycle Phases

\begin{tabular}{|c|c|c|c|c|c|c|}
\hline Country & $\begin{array}{c}\text { Monetary Policy } \\
\text { Stance }\end{array}$ & 1 or $2 *$ & Expansion & Slowdown & Depression & Recovery \\
\hline \multirow{4}{*}{$\begin{array}{l}\text { United } \\
\text { Kingdom }\end{array}$} & \multirow{2}{*}{ expansive } & 1 & 0.414 & 1.000 & 0.550 & 0.150 \\
\hline & & 2 & 0.141 & 0.176 & 0.129 & 0.035 \\
\hline & \multirow{2}{*}{ restrictive } & 1 & 0.586 & 0.000 & 0.450 & 0.850 \\
\hline & & 2 & 0.202 & 0.000 & 0.107 & 0.202 \\
\hline \multirow{4}{*}{ Czech Republic } & \multirow{2}{*}{ expansive } & 1 & 0.529 & 0.563 & 0.444 & 0.588 \\
\hline & & 2 & 0.130 & 0.130 & 0.116 & 0.145 \\
\hline & \multirow{2}{*}{ restrictive } & 1 & 0.471 & 0.438 & 0.556 & 0.412 \\
\hline & & 2 & 0.118 & 0.103 & 0.147 & 0.103 \\
\hline \multirow{4}{*}{ Euro Area } & \multirow{2}{*}{ expansive } & 1 & 0.421 & 1.000 & 1.000 & 0.481 \\
\hline & & 2 & 0.116 & 0.217 & 0.101 & 0.188 \\
\hline & \multirow{2}{*}{ restrictive } & 1 & 0.579 & 0.000 & 0.000 & 0.519 \\
\hline & & 2 & 0.162 & 0.000 & 0.000 & 0.206 \\
\hline \multirow{4}{*}{$\begin{array}{l}\text { United States } \\
\text { of America }\end{array}$} & \multirow{2}{*}{ expansive } & 1 & 0.526 & 0.643 & 0.706 & 0.441 \\
\hline & & 2 & 0.118 & 0.106 & 0.141 & 0.176 \\
\hline & \multirow{2}{*}{ restrictive } & 1 & 0.474 & 0.357 & 0.294 & 0.559 \\
\hline & & 2 & 0.107 & 0.060 & 0.060 & 0.226 \\
\hline \multirow{4}{*}{ Hungary } & \multirow{2}{*}{ expansive } & 1 & 0.647 & 0.563 & 0.615 & 0.286 \\
\hline & & 2 & 0.183 & 0.150 & 0.133 & 0.067 \\
\hline & \multirow{2}{*}{ restrictive } & 1 & 0.353 & 0.438 & 0.385 & 0.714 \\
\hline & & 2 & 0.098 & 0.115 & 0.082 & 0.164 \\
\hline \multirow{4}{*}{ Poland } & \multirow{2}{*}{ expansive } & 1 & 0.700 & 0.652 & 0.538 & 0.438 \\
\hline & & 2 & 0.192 & 0.205 & 0.096 & 0.096 \\
\hline & \multirow{2}{*}{ restrictive } & 1 & 0.300 & 0.348 & 0.462 & 0.563 \\
\hline & & 2 & 0.083 & 0.111 & 0.083 & 0.125 \\
\hline \multirow{4}{*}{ Sweden } & \multirow{2}{*}{ expansive } & 1 & 0.571 & 0.556 & 0.500 & 0.320 \\
\hline & & 2 & 0.103 & 0.128 & 0.128 & 0.103 \\
\hline & \multirow{2}{*}{ restrictive } & 1 & 0.429 & 0.444 & 0.500 & 0.680 \\
\hline & & 2 & 0.078 & 0.104 & 0.130 & 0.221 \\
\hline
\end{tabular}

*Note: 1 - share of quarters in the total number of quarters with the given financial cycle phase; 2 - share of quarters in the total number of quarters. Monetary policy is categorized as restrictive when real interest rate gap is above zero and as expansive when real interest rate gap is below zero.

Source: Authors 


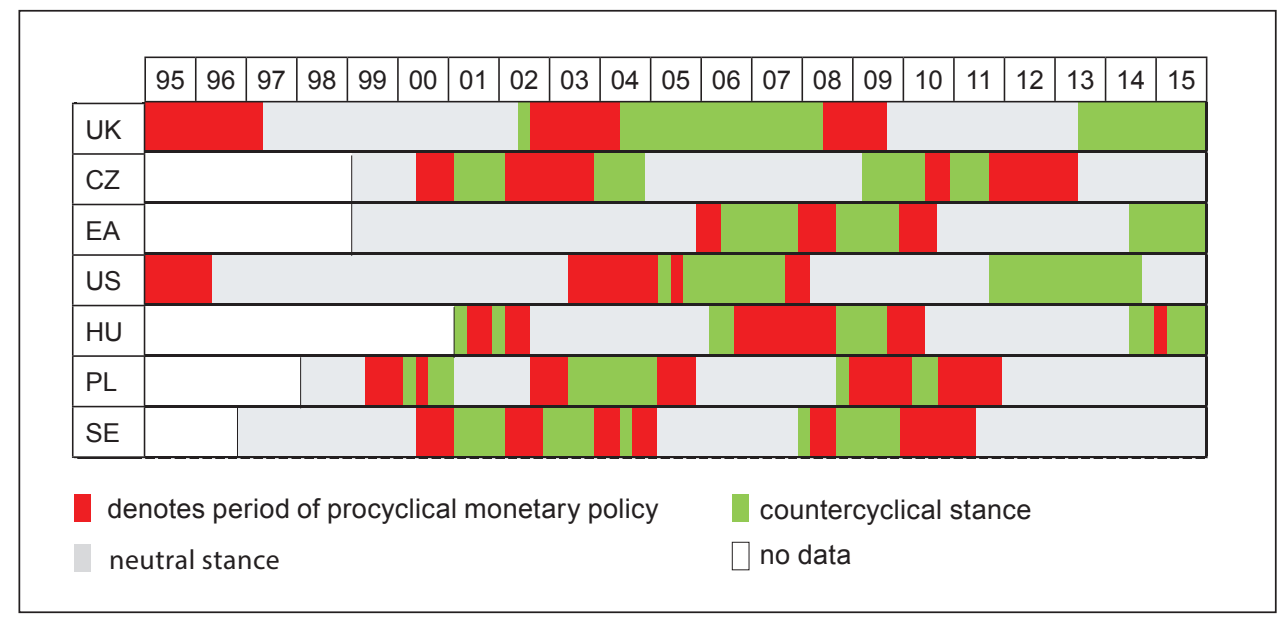

Source: Own work

We analyse how the procyclicality of monetary policy developed over time, especially in the run-up and after the start of the GFC (see Figure 2) in each country, as indicated by Laeven and Valencia (2012). Here, the results are heterogeneous. Both in the Euro Area, the UK and the US, central banks run countercyclical monetary policy during a few years before the outbreak of the crisis, and mainly natural afterwards. At the same time in Hungary, the monetary policy stance was procyclical in the run-up to the GFC and neutral in Sweden. In Poland and the Czech Republic, where no crisis was recorded according to Laeven and Valencia (2012), the monetary policy stance was natural before the GFC and later mixed.

The procyclicality of monetary policies towards a financial cycle mirrors the potential conflicts between monetary and macroprudential policies. The conflicts between both policies may be caused by i) different objectives (price and financial stability, ii) assigning mandates for price and financial stability to different authorities and iii) interrelations between macroprudential and monetary policy transmission channels that depend on tools used to achieve their objectives. However, both policies affect credit growth and lending rates.

The theoretical literature provides a common example of potential conflicts between these polices (see Table 4), for example, when inflation is below target and a strong risk of asset bubble exists at the same time. Macroprudential policy in this case should restrict bank credit growth, but it leads to the prolongation of the low inflation level and affects the monetary transmission mechanisms. Conversely, the monetary policy expansionary stance has an aversive effect on the systemic risk level. The low interest rate through the risk-taking channel may promote the accumulation of financial imbalances.

We empirically explore examples of conflicts between achieving price stability and stabilizing the financial cycle (see Table 5). We calculate the share of quarters in total sample in particular financial cycle phases with different policies interactions. We conduct 
the analysis under assumption that the inflation is either above or below the official numerical target. We calculated the instances of conflicts using both current and expected inflation, but the results were very similar (see Appendix for estimation method of expected inflation).

Table 4 | Theoretical Instances of Relations between Monetary and Macroprudential Policies

\begin{tabular}{|l|l|l|l|}
\hline & \multicolumn{1}{|c|}{$\begin{array}{c}\text { Inflation above } \\
\text { Target }\end{array}$} & \multicolumn{1}{|c|}{$\begin{array}{c}\text { Inflation Close } \\
\text { to Target }\end{array}$} & \multicolumn{1}{|c|}{$\begin{array}{c}\text { Inflation below } \\
\text { Target }\end{array}$} \\
\hline $\begin{array}{l}\text { Financial exuberance } \\
\text { (boom) }\end{array}$ & Complementary & Neutral & Conflicting \\
\hline No imbalances & Neutral & Neutral & Neutral \\
\hline $\begin{array}{l}\text { Financial deflation } \\
\text { (bust) }\end{array}$ & Conflicting & Neutral & Complementary \\
\hline
\end{tabular}

Source: Beau et al. (2012)

Table 5 | Empirical Examples of Potential Conflicts between Price Stability and Stabilizing the Financial Cycle (current inflation)

\begin{tabular}{|l|c|c|c|c|c|}
\hline \multirow{3}{*}{ Country } & $\mathbf{1}$ or $\mathbf{2}$ & Expansion & Slowdown & Depression & Recovery \\
\hline \multirow{3}{*}{ Cnited Kingdom } & 1 & 0.262 & 0.179 & 0.107 & 0.119 \\
\cline { 2 - 6 } & 2 & 0.082 & 0.000 & 0.129 & 0.118 \\
\hline \multirow{3}{*}{ Euro Area } & 1 & 0.087 & 0.000 & 0.058 & 0.072 \\
\cline { 2 - 6 } & 2 & 0.162 & 0.235 & 0.206 & 0.176 \\
\hline \multirow{3}{*}{ United States of America } & 1 & 0.116 & 0.130 & 0.000 & 0.319 \\
\cline { 2 - 6 } & 2 & 0.162 & 0.088 & 0.103 & 0.074 \\
\hline \multirow{3}{*}{ Hungary } & 2 & 0.035 & 0.094 & 0.106 & 0.188 \\
\hline \multirow{3}{*}{ Poland } & 1 & 0.267 & 0.167 & 0.083 & 0.150 \\
\cline { 2 - 6 } & 2 & 0.016 & 0.098 & 0.131 & 0.082 \\
\hline \multirow{2}{*}{ Sweden } & 1 & 0.233 & 0.055 & 0.055 & 0.082 \\
\cline { 2 - 6 } & 2 & 0.042 & 0.264 & 0.125 & 0.139 \\
\hline & 1 & 0.077 & 0.026 & 0.077 & 0.013 \\
\hline & 2 & 0.104 & 0.208 & 0.182 & 0.312 \\
\hline
\end{tabular}

Note: 1 -current inflation above target; 2 - current inflation below target

Source: Own work 
Overall, the share of periods with conflicting objectives is rather small but not negligible. In general, the degree of conflicting objectives (inflation above target in depression or inflation below target in expansion) is higher in expansion phase rather than in depression phase, where financial bust is usually associated with depression in the real economy. In case of the Czech Republic, the UK and Sweden the potential conflicting objectives are present in around $20 \%$ of quarters, while only in $10 \%$ of quarters in Poland and Hungary. However, the differences cannot be considered as significant.

The share of quarters with complimentary objectives is noticeable. Also the propensity of complimentary objectives (inflation above target in cyclical expansion or below target in cyclical depression) is lower in depression phase than in expansion phase. In expansion, the credit boom might be moderated "as a by-product" of restrictive monetary policy targeted to reduce inflationary pressure in the overheated economy, thus contributing to the achievement of both price and financial stability. In depression phase of the financial cycle expansionary monetary policy helps achieve the inflation target and supports financial stability by decreasing the negative credit-to-GDP gap. However, the question of whether or not unconventional monetary instruments can help fulfil central banks' inflation target and financial stability mandates remains. An increasing number of studies have provided evidence that unconventional monetary policy and negative interest rate policy can also increase systemic risk via channels that are not reflected in the financial cycle gap (e.g. increase in risk of asset bubbles and market volatility, see Borio and Zabai, 2016). Therefore, macroprudential policy should be more active in an unconventional monetary policy environment than when interest rates are above zero.

The share of quarters with complimentary objectives relatively high in Hungary, the UK and Poland (reaching 36\%-40\%). Overall results shows that, on average, cases of complementariness between price and financial stability are more prominent $(22 \%-40 \%$ of quarters) than cases with conflicting objectives $(10 \%-22 \%$ of quarters), which holds for all countries in the sample. At the same time, the expansionary phase of the cycle is the most frequent case of either conflicts of complementariness of objectives.

The implications for the central banks as indicated in Tables 3 and 5 are similar: monetary policy decisions might contribute to build-up of cyclical financial imbalances. Therefore active macroprudential policy action is warranted, especially when the financial cycle is expanding. We cannot exclude the existence of potential conflicts between price and financial stability objectives, and central banks would pursue inflation as the primary target in case of any conflict. Mitigating conflicts between objectives may require establishing coordination mechanisms, which, however, depend on the institutional safety net arrangements. For example in the UK, the Czech Republic and Hungary, the central bank has the final say in both monetary and macroprudential policies, while in the US, Poland and Sweden the central bank is only sharing the responsibility for macroprudential policy with other safety net bodies. In the first case, the conflict might be at least somewhat eased by strengthening the internal coordination mechanisms within the central bank. In the second case clear cooperation and accountability mechanisms between safety net institutions - having their separate objectives - are necessary. 
Our results support the central banking framework proposed by Frait and Komárková (2012), who argued that financial stability is an objective of the central bank, which determines its short-term policy choices but does not change its medium- to longterm commitment to price stability. However, as micro- and macroprudential tools and prudential regulations may be insufficient in curbing systemic risks, monetary policy can be used pre-emptively when cyclical imbalances accumulate but only as a secondary measure (co-insurance). Targeted prudential tools may be prone to regulatory arbitrage. This situation entails communication challenges when implementing leaning against the wind. Financial stability should be a factor for monetary policy decisions, especially when systemic risk assessment indicates that a certain degree of financial vulnerability (e.g. credit-to-GDP gap threshold) has been exceeded. However, to what extent monetary policy (e.g. by the interest rate changes) is effective in leaning without excessively damaging the real economy remains to be seen (Assenmacher-Wesche and Gerlach, 2010). The need for coordination and synergies between monetary and macroprudential policies is especially prominent in small open economies, where the effectiveness and independence of national monetary policy may be impeded by capital flows, exchange rate fluctuations and foreign monetary policy.

\section{Conclusions}

Using different approaches, we assessed monetary policy procyclicality of seven central banks towards financial cycle phases in 1995-2015. Our research provides evidence that in financial cycle expansion phase, monetary policy is on average expansive for more than $50 \%$ of cases. This indicates procyclical behaviour of monetary policy which may potentially amplify cyclical financial imbalances (as measured using the credit/GDP gap). Monetary policy is more likely to work countercyclically in the depression phase of financial cycle supporting the recovery of both financial and real spheres of the economy. Yet, the complementariness between both objectives is much more frequent than cases with conflicting objectives in UK, Euro Area and the US.

Our results show that the monetary policy procyclicality is a non-negligible issue, which contributes to the ongoing discussion in the literature on how to limit the conflicts between price and financial stability. The interrelations and the degree of the need for coordination among analysed policies remain controversial. Scholars such as Hahm et al. (2012) have suggested that monetary and macroprudential policies should be separated. Conversely, others provide evidence that monetary policies that systematically include financial factors support the dampening of the financial cycle, thus improving output in the long run (Borio et al., 2016). Our results support the views of Malovaná and Frait (2016) that monetary tightening coincides with lower credit-to-GDP and that accommodative monetary policy may contribute to a build-up of financial vulnerabilities.

The analysed co-movement between monetary policy and the financial cycle does not directly translate into exploring causality links and transmission channels between monetary policy, macroprudential policy and the financial cycle. As the macroprudential measures 
have been introduced only in recent years, exploring their impact on the financial cycle - apart from the impact of monetary policy - would be the desired direction of research in the future. There are already first attempts to comprehensibly conceptualize and model the interactions between transmission mechanisms of monetary policy and prudential policies (Beyer et al., 2017). Further, studying the effect of macroprudential tools on business cycle/inflation is a valuable research area. Apart from obtaining a wider country sample, our study may be extended by considering not only the financial cycle but also the housing and equity market cycles. Moreover, whether or not monetary policy procyclicality depends on the interrelations between business and financial cycles and on structural factors (i.e. currency regime or institutional design) is worth exploring.

\section{Appendix}

\section{Expected Inflation and Financial Cycle}

Empirical Examples of Potential Conflicts between Price Stability and Stabilizing the Financial Cycle (expected inflation)

\begin{tabular}{|l|c|c|c|c|c|}
\hline \multirow{2}{*}{ Country } & 1 or 2 & Expansion & Slowdown & Depression & Recovery \\
\hline \multirow{3}{*}{ United Kingdom } & 1 & 0.226 & 0.167 & 0.096 & 0.131 \\
\cline { 2 - 6 } & 2 & 0.119 & 0.012 & 0.133 & 0.107 \\
\hline \multirow{3}{*}{ Czech Republic } & 1 & 0.103 & 0.000 & 0.074 & 0.088 \\
\cline { 2 - 6 } & 2 & 0.147 & 0.224 & 0.191 & 0.162 \\
\hline \multirow{3}{*}{ United States of America Area } & 1 & 0.118 & 0.132 & 0.000 & 0.269 \\
\cline { 2 - 6 } & 2 & 0.162 & 0.088 & 0.103 & 0.119 \\
\hline \multirow{3}{*}{ Hungary } & 2 & 0.179 & 0.083 & 0.096 & 0.214 \\
\hline \multirow{2}{*}{ Poland } & 1 & 0.233 & 0.183 & 0.085 & 0.133 \\
\cline { 2 - 6 } & 2 & 0.050 & 0.083 & 0.119 & 0.100 \\
\hline \multirow{2}{*}{ Sweden } & 1 & 0.236 & 0.056 & 0.056 & 0.085 \\
\cline { 2 - 6 } & 2 & 0.042 & 0.264 & 0.125 & 0.127 \\
\hline & 1 & 0.078 & 0.039 & 0.078 & 0.026 \\
\hline & 2 & 0.104 & 0.195 & 0.182 & 0.289 \\
\hline
\end{tabular}

Note: 1 - expected inflation above the target, 2 - expected inflation below the target Source: Authors. 


\section{Parameters for Estimation of Expected Inflation}

\begin{tabular}{|l|c|c|}
\hline Country & $\boldsymbol{\mu}_{0}$ & $\boldsymbol{\mu}_{1}$ \\
\hline United Kingdom & $\begin{array}{c}-0.0239 \\
(0.6764)\end{array}$ & $\begin{array}{c}0.3383^{* * *} \\
(0.0018)\end{array}$ \\
\hline Czech Republic & $\begin{array}{c}-0.0105 \\
(0.9171)\end{array}$ & $\begin{array}{c}0.3973^{* * *} \\
(0.0001)\end{array}$ \\
\hline Euro Area & $\begin{array}{c}-0.0109 \\
(0.8341)\end{array}$ & $\begin{array}{c}0.311^{* *} \\
(0.0104)\end{array}$ \\
\hline United States of America & $\begin{array}{c}-0.0182 \\
(0.8292)\end{array}$ & $\begin{array}{c}0.2112^{*} \\
(0.0561)\end{array}$ \\
\hline Hungary & $\begin{array}{c}-0.1 \\
0.4077)\end{array}$ & $\begin{array}{c}0.4375^{* * *} \\
(0.0005)\end{array}$ \\
\hline Poland & $\begin{array}{c}-0.1021 \\
(0.3081)\end{array}$ & $\begin{array}{c}0.4578^{* * *} \\
(0.0001)\end{array}$ \\
\hline Sweden & $\begin{array}{c}0.0094 \\
(0.8892)\end{array}$ & $\begin{array}{c}0.3870^{* * *} \\
(0.0006)\end{array}$ \\
\hline
\end{tabular}

Note: $t$-statistics are in parentheses, ${ }^{*} p<0.1,{ }^{* *} p<0.05,{ }^{* * *} p<0.01$

Source: Authors.

\section{References}

Agur, I., Demertzis, M. (2012). Excessive Bank Risk Taking and Monetary Policy. European Central Bank. Working Paper No. 1457.

Assenmacher-Wesche, K., Gerlach, S. (2010). Financial Structure and the Impact of Monetary Policy on Property Prices. Institute for Monetary and Financial Stability, University of Frankfurt. Available at: http://www.riksbank.se/Upload/Dokument_riksbank/Kat_ foa/2009/6_8nov/Assenmacher-Wesche-Gerlach.pdf

Athanasoglou, P. P., Daniilidis, I., Delis, M. D. (2014). Bank Procyclicality and Output: Issues and Policies. Journal of Economics and Business, 72, 58-83, https://doi.org/10.1016/j. jeconbus.2013.10.003

Bauer, G., Pasricha, G., Sekkel, R., Terajima, Y. (2016). The Global Financial Cycle, Monetary Policies and Macroprudential Regulations in Small, Open Economies. Bank of Canada. Staff Working Paper No. 38.

Baxa, J., Horváth, R., Vašíček, B. (2013). Time-Varying Monetary-Policy Rules and Financial Stress: Does Financial Instability Matter for Monetary Policy? Journal of Financial Stability, Elsevier, 9(1), 117-138, https://doi.org/10.1016/j.jfs.2011.10.002

Beau, D., Clerc, L., Mojon, B. (2012). Macro-Prudential Policy and the Conduct of Monetary Policy. Banque de France. Available at: http://www.benoitmojon.com/pdf/Beau-Clerc-Mojon.pdf

Beyer, A., Nicoletti, G., Papadopoulou, N., Papsdorf, P., Rünstler, G., Schwarz, C., Sousa, J., Vergote, O. (2017). The Transmission Channels of Monetary, Macro- and Microprudential Policies and their Interrelations. ECB. Occasional Paper Series No. 191. 
Blanchard, O., Cerutti, E., Summers, L. (2015). Inflation and Activity - Two Explorations and Their Monetary Policy Implications. IMF. Working Paper No. WP/15/230, https://doi.org/10.2139/ ssrn.2689049

Bordo, M. D., Lane, J. L. (2012). Does Expansionary Monetary Policy Cause Asset Price Booms; Some Historical and Empirical Evidence. Paper presented at Sixteenth Annual Conference of the Central Bank of Chile.

Borio, C. (2014a). The Financial Cycle and Macroeconomics: What Have We Learnt? Journal of Banking \& Finance, Elsevier, 45(C), 182-198, https://doi.org/10.1016/j. jbankfin.2013.07.031

Borio, C., Disyatat, P., Drehmann, M., Juselius, M. (2016). Monetary Policy, the Financial Cycle and Ultra-Low Interest Rates. Bank for International Settlements. Working Papers No. 569.

Borio, C., Drehmann, M. (2009). Assessing the Risk of Banking Crises - Revisited. Bank for International Settlements. Quarterly Review (March). Available at: http://www.bis.org/ publ/qtrpdf/r_qt0903e.pdf

Borio, C., Drehmann, M., Gambacorta, L., Jiménez, G., Trucharte C. (2010). Countercyclical Capital Buffers: Exploring Options. Bank for International Settlements. Working Paper No. 317, https://doi.org/10.2139/ssrn.1648946

Borio, C., Drehmann, M., Tsatsaronis, K. (2011). Anchoring Countercyclical Capital Buffers: The Role of Credit Aggregates. International Journal of Central Banking, 7(4), 189-240.

Borio, C., Drehmann, M., Tsatsaronis, K. (2012). Characterising the Financial Cycle: Do Not Lose Sight of the Medium Term! Bank for International Settlements. Working Papers No. 380.

Borio, C., Zabai, A. (2016). Unconventional Monetary Policies: A Re-Appraisal. Bank for International Settlements. Working Paper No. 570.

BSCB (2010). Guidance for National Authorities Operating the Countercyclical Capital Buffer. Bank for International Settlements. Working Paper. Available at: http://www.bis.org/publ/ bcbs187.pdf

Calderon, C., Fuentes, J. R. (2014). Have Business Cycles Changed over the Last Two Decades? An Empirical Investigation. Journal of Development Economics, Elsevier, 109, 98-123, https://doi.org/10.1016/j.jdeveco.2014.03.001

Claessens, S., Kose, M. A., Terrones, M. E. (2011). How do Business and Financial Cycles Interact? International Monetary Fund. Working Paper No. 11/88.

Delis, M. D., Karavias, Y. (2015). Optimal versus Realized Bank Credit Risk and Monetary Policy. Journal of Financial Stability, Elsevier, 16, 13-30, https://doi.org/10.1016/j.jfs.2014.11.004

ESRB (2014). Operationalising the Countercyclical Capital Buffer: Indicator Selection, Threshold Identification and Calibration Options. European Systemic Risk Board. Occasional Paper Series No. 5.

Fendoglu, S. (2014). Optimal Monetary Policy Rules, Financial Amplification, and Uncertain Business Cycles. Journal of Economic Dynamics and Control, Elsevier, 46, 271-305, https://doi.org/10.1016/j.jedc.2014.06.008

Frait, J., Komárková, Z. (2012). Macroprudential Policy and Its Instruments in a Small EU Economy. Research and Policy Notes, vol. 3/2012. Available at: https://www.cnb.cz/en/research/ research_publications/irpn/2012/rpn_03_2012.html

Geršl, A., Seidler, J. (2015). Countercyclical Capital Buffers and Credit-to-GDP Gaps: Simulation for Central, Eastern, and Southeastern Europe. Eastern European Economics, 53(6), 439-465, https://doi.org/10.1080/00128775.2015.1102602 
Giammarioli, N., Valla, N. (2004). The Natural Real Interest Rate and Monetary Policy: A Review. Journal of Policy Modeling, 26(5), 641-660, https://doi.org/10.1016/j.jpolmod.2004.01.007

Giese, J., Andersen, H., Bush, O., Castro, C., Farag, M., Kapadia, S. (2014). The Credit-to-GDP Gap and Complementary Indicators for Macroprudential Policy: Evidence from the UK. International Journal of Finance and Economics, 19(1), 25-47, https://doi.org/10.1002/ ijfe.1489

Hahm, J-H, Mishkin, F. S., Shin, H. S., Shin. K. (2012). Macroprudential Policies in Open Emerging Economies. NBER. Working Paper No. 17780, https://doi.org/10.3386/w17780

Hiebert, P., Klaus, B., Peltonen, T., Schüler, Y.S., Welz, P. (2014). Capturing the Financial Cycle in Euro Area Countries. European Central Bank, Financial Stability Review (November). Available at: https://www.ecb.europa.eu/pub/pdf/other/financialstabilityreview201411. en.pdf

Illing, G. (2007). Financial Stability and Monetary Policy - a Framework. CESIFO. Working Paper Series No. 1971. Available at: https://ssrn.com/abstract=985275

IMF (2013). The Interaction of Monetary and Macroprudential Policies. International Monetary Fund.

Ioannidou, V., Ongena, S., Peydro, J. L. (2008). Monetary Policy, Risk-Taking and Pricing: Evidence from a Quasi-Natural Experiment. Paper presented at the 9th Jacques Polak Annual Research Conference.

Iwanicz-Drozdowska, M., Witkowski, B. (2016). Credit Growth in Central, Eastern, and SouthEastern Europe: The Case of Foreign Bank Subsidiaries. International Review of Financial Analysis, 43, 146-158, https://doi.org/10.1016/j.irfa.2015.11.010

Jiménez, G., Ongena, S., Peydro, J. L., Hazardous, J. S. (2008). Times for Monetary Policy: What Do Twenty-Three Million Bank Loans Say about the Effects of Monetary Policy on Credit Risk? Journal of the Econometric Society, 82(2), 463-505, https://doi.org/10.3982/ECTA10104

Kaminsky, G., Reinhart, G., Végh, C.A. (2004). When It Rains, it Pours: Procyclical Capital Flows and Macroeconomic Policies. NBER. Working Paper No. 10780, https://doi.org/10.3386/w10780

Kollintzas, T., Konstantakopoulou, I., Tsionas, E. (2011). Stylized Facts of Money and Credit over the Business Cycles. Applied Financial Economics, 21(23), 1735-1755, https://doi.org/10.10 80/09603107.2011.583215

Laeven, L., Valencia, F. (2012). Systemic Banking Crises Database: An Update. International Monetary Fund. Working Paper No. WP/12/163.

Landier, A., Sraer, D., Thesmar, D. (2011). The Risk-Shifting Hypothesis: Evidence from Subprime Originations. TSE. Working Paper No. 11.

Malovaná S., Frait, J. (2016). Monetary Policy and Macroprudential Policy: Rivals or Teammates? Česká Národní Banka. Working Paper Series No. 6/2016.

McGettigan, D., Moriyama, K., Noah, N., Ntsama, J., Painchaud, F., Qu, H., Steinberg, C. (2013). Monetary Policy in Emerging Markets: Taming the Cycle. IMF. Working Paper No. 13/96.

Merrouche, O., Nier, E. (2010). What Caused the Global Financial Crisis?-Evidence on the Drivers of Financial Imbalances 1999-2007. International Monetary Fund. Working Paper No. 10/265, https://doi.org/10.2139/ssrn.1735474

Mohr, M. (2005) A Trend-Cycle(Season) Filter. European Central Bank. Working Paper No. 499.

Nicolo, G. D., Dell'Ariccia, G., Laeven, L., Valencia, F. (2010). Monetary Policy and Bank Risk Taking. IMF Staff Position Note. Available at: https://www.imf.org/external/pubs/ft/spn/2010/ spn1009.pdf 
Olszak M., Pipien M. (2016). Cross Country Linkages as Determinants of Procyclicality of Loan Loss Provisions. The European Journal of Finance, 22(11), 965-984, https://doi.org/10.1080/ $1351847 X .2014 .983138$

Persson, M. (2009). Household Indebtedness in Sweden and Implications for Financial Stability - the Use of Household-Level Data. Bank for International Settlements. Papers No. 46. Available at: https://core.ac.uk/download/pdf/6863818.pdf

Ross, M., Schmidt, U. (2011). The Importance of Time Series Extrapolation for Macroeconomic Expectations. Kiel Institute. Working Paper No. 1723.

Shin, H. S. (2008). Procyclicality and the Search for Early Warning Indicators. International Monetary Fund. Working Paper No. WP/13/258.

Smaga, P. (2014). The Concept of Systemic Risk. London School of Economics. SRC Special Paper No 5. Available at: https://ssrn.com/abstract $=2477928$

Stremmel, H. (2015). Capturing the Financial Cycle in Europe. European Central Bank. Working Paper No 1811.

Taylor, J. (2007). Housing and Monetary Policy. NBER. Working Paper No. 13682, https://doi. org/10.3386/w13682 